\title{
Willingness of community based health insurance uptake and associated factors among urban residents of Oromia regional state, Oromia, Ethiopia, a cross-sectional study
}

\author{
Alem Deksisa ${ }^{1 *}$ D, Meyrema Abdo ${ }^{1}$, Ebrahim Mohamed ${ }^{1}$, Daniel Tolesa', Sileshi Garoma ${ }^{1}$, Abate Zewdie ${ }^{2}$,
} Melese Lami ${ }^{2}$, Dinka Irena ${ }^{2}$, Dereje Abdena ${ }^{2}$ and Hunde Lemi ${ }^{1}$

\begin{abstract}
Background: Globally, Millions of people cannot use health services because of the fear of payment for the service at the time of service delivery. From the agenda of transformation and the current situation of urbanization as well as to ensure universal health coverage implementing this program to the urban resident is mandatory. The aim of this study is to assess the willingness of community-based health insurance $(\mathrm{CBHI})$ uptake and associated factors among urban residents of Oromia regional state, Oromia, Ethiopia, 2018.

Methods: A community-based cross-sectional study was conducted. From the total of eighteen towns; six towns which account for $33 \%$ of the total were selected randomly for the study. One population proportion formula was employed to get a total of 845 households. A pre-tested, semi-structured interviewer-administered questionnaire was used to collect the required data. Double-Bounded Dichotomous Choice Variant of the contingent valuation method was used to assess the maximum willingness to pay for the scheme, and a multiple logistic regression model was used to determine the effect of various factors on the willingness to join and willingness to pay for the households.
\end{abstract}

Result: About 839 (99.3\%) of the respondents participated. The mean ages of the respondents were 40.44(SD \pm 11.12) years. 621 (74.1\%) ever heard about CBHI with 473 (56.3\%) knowing the benefits package. Out of 839, 724 (86.3\%) were willing to uptake $\mathrm{CBHI}$ of which 704 (83.9\%) were willing to pay if $\mathrm{CBHI}$ established in their town.

Conclusion: If $\mathrm{CBH}$ established about $86.3 \%$ of the households would enroll in the scheme. Having education, with a family size between $3 \& 6$, having difficulty in paying for health care and less than 20mins it took to reach the nearest health facility were the independent predictors of the willingness of $\mathrm{CBHI}$ uptake. The Oromia and Towns Health Bureau should consider the availability of health facilities near to the community and establishing $\mathrm{CBHI}$ in the urban towns.

Keywords: Willingness, Community based health insurance, Urban, Households

\footnotetext{
*Correspondence: alexdugna@gmail.com; alemdeks@yahoo.com

'Department of Public Health, Adama Hospital Medical College, Adama, Ethiopia

Full list of author information is available at the end of the article
}

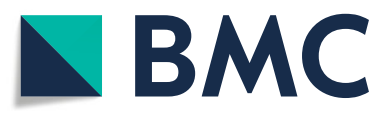

(c) The Author(s). 2020 Open Access This article is licensed under a Creative Commons Attribution 4.0 International License, which permits use, sharing, adaptation, distribution and reproduction in any medium or format, as long as you give appropriate credit to the original author(s) and the source, provide a link to the Creative Commons licence, and indicate if changes were made. The images or other third party material in this article are included in the article's Creative Commons licence, unless indicated otherwise in a credit line to the material. If material is not included in the article's Creative Commons licence and your intended use is not permitted by statutory regulation or exceeds the permitted use, you will need to obtain permission directly from the copyright holder. To view a copy of this licence, visit http://creativecommons.org/licenses/by/4.0/ The Creative Commons Public Domain Dedication waiver (http://creativecommons.org/publicdomain/zero/1.0/) applies to the data made available in this article, unless otherwise stated in a credit line to the data. 


\section{Background}

Community-based health insurance schemes help to give financial protection and decrease direct out- of-pocket payment for health care based on the assumption of risk-pooling and community solidarity to risks of falling sick [1]. CBHI schemes allow people's resources to be pooled to cover the costs of unpredictable health problems and keep individuals and households from the risk of catastrophic medical expenses in exchange for out-ofpocket payments $[2,3]$.

To achieve universal coverage for health care; government and donor agencies in a number of developing countries are not implementing Community-based health insurance schemes (CBHI) as social protection and an alternative measure. Community-based health insurance schemes are becoming increasingly recognized as one of health care financing strategy in developing country [4].

The health sector transformation plan (HSTP) of Ethiopia has put very motivating goals and desires to renovate the health system to deliver equitably and quality health cares. It is the first the envisage of stage of Ethiopia path towards universal health coverage through strengthening primary health care and as part of the second growth and transformation plan (GTP II) of the country. The main programs of HSTP are ensuring equity and quality health care services, the information revolution, woreda (the third-level-administrative divisions of Ethiopia) transformations, and caring, respectful and compassionate health workforce [5].

The three goals of woreda transformation program are: developing high-performing primary health care units (PHCU), the graduation of model Kebeles (the smallest unit of local government in Ethiopia), and achievement of universal health coverage with financial risk protection; which focuses on CBHI [6].

After successful completion of the 20-years health sector development program (HSDP); the Government of Ethiopia developed a road map in which the health sector envisioned beyond strengthening primary health care unit was placed as a strategy. Health sector transformation plan is part of this strategy which is implemented from the Ethiopian fiscal year 2008 to 2012 (July 2015 June 2020) [5, 7].

As part of health care financing strategy, the government of Ethiopia endorsed and launched CBHI scheme in 13 pilot woreda in Amahara, Oromia, south nation nationalities peoples and Tigray regions in 2010/11 to provide a risk protection mechanism for those employed in the rural and the informal sectors. The 13 pilot woredas are still implementing $\mathrm{CBHI}$ and they are on the way to expand it to 185 woredas [8].

Community-Based Health Insurance (CBHI) scheme in Oromia began in 2001 Ethiopian fiscal year (EFY) in four zones and four woredas and currently expanded into 134 additional woredas distributed among all zones. The objective of the scheme is to improve health service utilization by reducing direct out of pocket payments and improve the quality of health services [9].

Even though enormous activities were undertaken to guide and support the program since the regional cabinet passed a decision to expand the program, still the performance was very low ranging from $23 \%$ enrolment rate in the pilot woredas to $25 \%$ in the two phase expansions of 71 woredas [10].

In the current study area, there are no published data on demand of CBHI. It is believed that this study will help policy makers to address factors which affect the HHs willingness to uptake (WTU) make the benefit of planned CBHI scheme. The objective of this study was to assess willingness of community based health insurance uptake (WCBHIU) and associated factors among urban towns of Oromia region, Ethiopia, 2018.

\section{Methods \\ Study design and setting}

The community-based cross-sectional study design was conducted. The study was conducted in six towns of Oromia regional state from May 26 to July 30, 2018. Oromia regional state is the first populous and broader state among the nine regional states of Ethiopia. It's bordered with all regional states except Tigray regional state and has two international borders Kenya with South and South Sudan with West. Administratively, Oromia regional state is composed of twenty zones and eighteen towns which are subdivided into 333 woredas (the smaller administrative unit) and 7011 Kebeles (the smallest administrative unit). Projections from the 2007 population and housing census estimate the total population for the year $2017 / 18$ to be $36,839,051$ with the sex ratio between males and female is almost equal(1:1) and average annual population growth rate of $2.9 \%$ (\%2.7 \& $\% 4.6$ in rural and urban respectively). On average 123 populations live per $\mathrm{Sq} . \mathrm{Km}$ and there is a variation from one zone to another zone. In the year 2017, there are 79 hospitals, 1366 health centers, 6559 health posts, 2 regional laboratory and 7 blood bank unit government health facilities and also 7 private hospital, 150 private health centers, different level 3149 private clinics and 1701 pharmacies, 8 and 5 government development organization hospitals, and health centers respectively providing health services in the region. The health service coverage of the region is $97 \%$ \& $98 \%$ by health centers and health post respectively.

\section{Sample size determination}

The sample size was calculated using a single population proportion formula by "Taro Yamane" [11], as follows; 


$$
n=(Z \propto / 2 p(1-p)) / d^{2}
$$

$\mathrm{P}=$ expected rate of willingness to join a communitybased health insurance scheme $=0.5$ (since there is no Urban willingness to join study conducted in the country so far)

$$
\begin{aligned}
& \mathbf{d}=\text { Margin of sampling error tolerated }=5 \% \\
& =\text { Critical value at } 95 \% \text { confidence interval of certainty }(1.96) \\
& =(1.96) 2 * 0.5(1--0.5) /(0.05) 2=384
\end{aligned}
$$

By adding the expected non-response rate of $10 \%$, the sample size was $290 \mathrm{HHs}$, but since the study utilized multi-stage sampling, this sample size was multiplied by 2 for the design effect. Hence, the final sample sizes for this study is $2 * 384+10 \%=845$.

\section{Study population}

The sample was obtained using stratified multi-stage simple random sampling technique. Eighteen selected towns were stratified into three strata based on their rank given by the regional state government. Two towns were selected randomly from the first level and from 2 " A" level three and one from 2 "B" level. Finally, six towns from all levels were selected randomly from all towns in the region. Twelve kebeles (the smallest administrative division); two from each were selected using lottery methods from all selected study towns. In the second stage, 845 households were selected using computerized simple random sampling technique. The households who are selected to participate in the study were allocated proportionately to the size of households of those kebeles. The sampling frame was developed by using the identification number of the houses which were given by the kebeles (Fig. 1).

\section{Data collection}

Data were collected using an Interviewer administered pretested, a structured and standardized questionnaire by 12 trained data collectors. The questionnaire was adapted from previous similar studies for data collection purpose $[3,7,9]$ and. It was initially prepared in English and then was translated into Afan Oromo (the local language) and later on back to English to check for consistency. Supervisors followed the data collectors and provided any necessary correction on the spot.

'Double-bounded dichotomous choice variant of the contingent valuation method' was used in which respondents were asked two successive binary questions for their ability to pay the stated number of premiums for CBHI. First the respondents were asked their ability to pay 500ETB initial bid per year per household for CBHI. The second question was conditioned on the responses to the first answer. That means if the response was "yes, they were asked their ability to pay double of the first bid (premium) for CBHI. If their responses to initial bid was "no," they were asked for their ability to pay half of the initial bid. Finally, open-ended question for those who did not pick a 'yes' for either the first or second option was used to enable respondents to pick lower amounts (as low as zero) or higher amounts (higher than the stated options in the double bounded dichotomous choice contingent valuation Method).This helped the researchers to separate those respondents whose real ability to pay were zero from those respondents who were willing to pay something but less than the lowest bid.

\section{Data analysis}

The collected data were cleaned, coded and entered into EPI Data version 3.1 and then exported for analysis to SPSS version 20. The data was analyzed using binary and multivariate logistic regressions to determine the effect of various factors on the outcome variable. The results were presented in the form of tables, figures and text using frequencies and summary statistics such as standard deviation, mean, and percentage to describe the study population in relation to relevant variables. The degree of association between dependent and independent variables was assessed using odds ratio with 95\% confidence interval and $p$-value $<0.05$ declared statistical significance.

\section{Results}

\section{Socio-demographic characteristics of respondents}

A total of 845 participants from six urban towns of Oromia was planned to participate in the study, out of which 830 study subjects were enrolled; with 322 (39.2\%) from Adama, 101 (12.1\%) from Asella, 94 (11.3\%) from Ambo, 108 (13.2\%) were from Nekemte, 147 (18\%) were from Shashemene and the rest $6.2 \%$ from Holleta town; making a response rate of $98.2 \%$. The reason for nonparticipation was unwillingness.

Among study participants 315 (38\%) were in the age group of 35-44 years with median 38 years. (interquartile range of 32 to 46 years). 449 (54.4\%) were male. 438 $(52.8 \%)$ were husbands by a head to the household followed by 366 (44.1\%) spouses by a head to the household. About 424 (51.1\%) were orthodox by religion, and 659 (79.4\%) were married. By occupation 288 (34.7\%) were merchants and 293 (35.2\%) were educated within grade 9-12. The average family size of the household was 3-6 for 455 (54.8\%) of the participants (Table 1).

\section{Social capital and horizontal trust}

Almost half of the respondents 422 (50.8\%), 426 (51.3\%), 420 (50.6\%), 408 (49.2\%), 409 (49.3\%), 430 (51.8\%) and 408 (49.2\%) disagreed with the statements; 'most villagers of the village can be trusted', 'Most villagers willing to return; what doesn't belong to them', 'Neighbors 


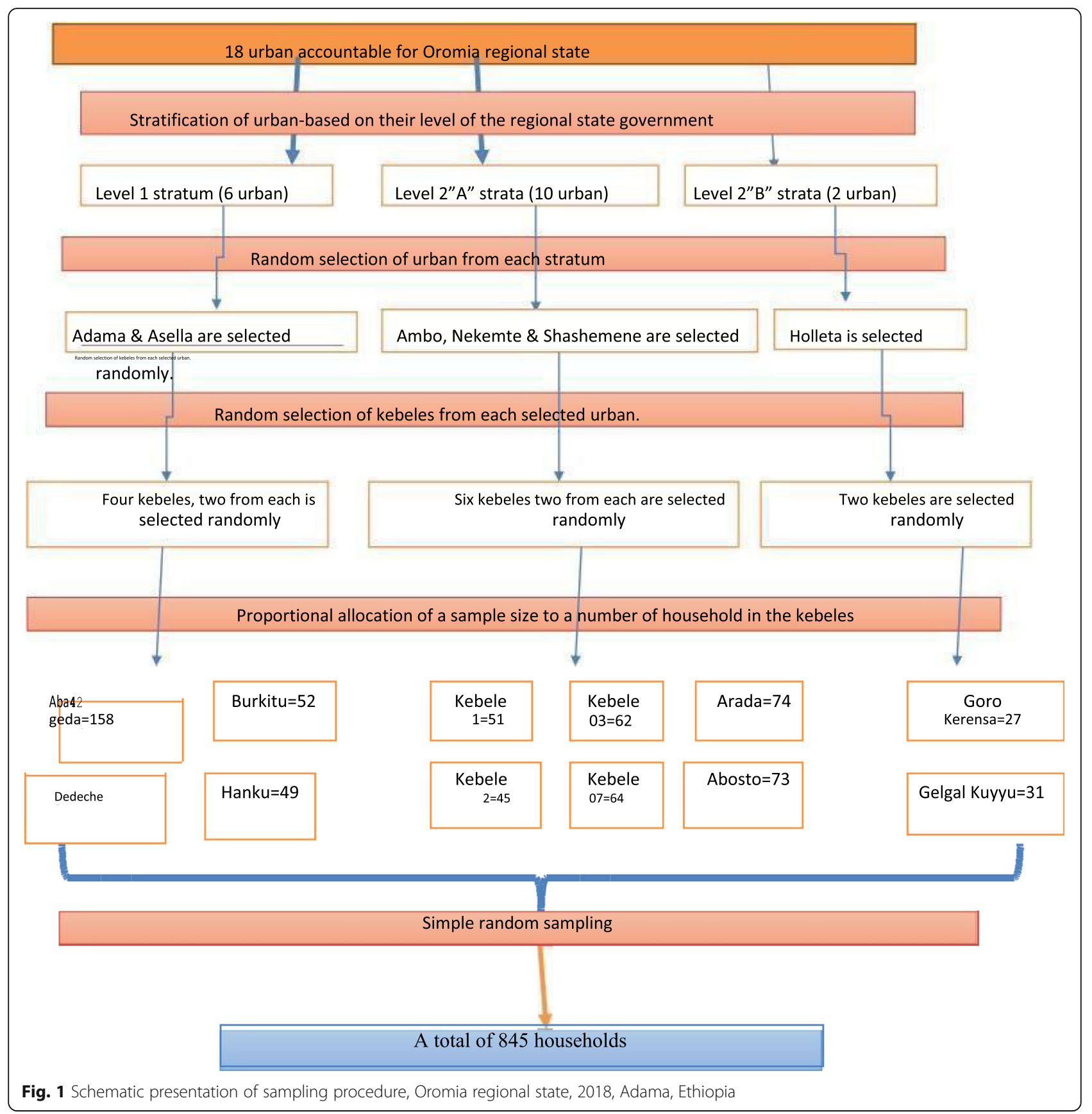

can be trusted', 'Village leaders are trusted', 'Villagers concern issues not only relate to themselves', 'Villagers provide help if someone really needs it and 'Lend money to your neighbors', respectively. About 381 (45.9\%), 332 (40\%) and 489 (58.9\%) disagreed with the statements: 'Most villagers of the village try to take advantage', 'Were Village had a large Family would be a member of this family and I would like to support a project that might benefit other villagers, respectively. A total of 715 respondents disagreed with overall horizontal trust statements (Table 2).

\section{Health and health-related factors}

Majority of the respondents $380(45.8 \%)$ said the health status of their family is good. Only $95(11.4 \%)$ had a chronic illness and/or disability. 485 (58.4\%) of respondents and $516(62.2 \%)$ of respondents family members had encountered an illness in the last 12 months. Latest illness Episode 142 (17.1\%) occur within the last 1 month followed by 136 (16.4\%) occurring within 7-12 months. Of which 501 (60.4\%) got treatment from different facilities and 216 (26\%) from private health facility; as 180 (21.7\%) chose for its service is efficacious. The total health 
Table 1 Distribution of socio-demographic characteristics of respondents who participated in the survey, urban towns of Oromia, 2018, Ethiopia

\begin{tabular}{|c|c|c|}
\hline Variables & Frequency & Percent (\%) \\
\hline \multicolumn{3}{|l|}{ Age category } \\
\hline $15-24$ & 25 & 3.0 \\
\hline $25-34$ & 221 & 26.6 \\
\hline $35-44$ & 315 & 38.0 \\
\hline $45-54$ & 168 & 20.2 \\
\hline$>54$ & 101 & 12.2 \\
\hline \multicolumn{3}{|l|}{ Sex } \\
\hline Male & 449 & 54.1 \\
\hline Female & 381 & 45.9 \\
\hline \multicolumn{3}{|c|}{ Relation to the head of the $\mathrm{HH}$} \\
\hline Husband & 438 & 52.8 \\
\hline Spouse & 366 & 44.1 \\
\hline Child & 18 & 2.2 \\
\hline Others & 8 & 1.0 \\
\hline \multicolumn{3}{|l|}{ Religion } \\
\hline Orthodox & 424 & 51.1 \\
\hline Muslim & 141 & 17.0 \\
\hline Protestant & 246 & 29.6 \\
\hline Catholic & 18 & 2.2 \\
\hline Others & 1 & .1 \\
\hline \multicolumn{3}{|l|}{ Ethnicity } \\
\hline Amhara & 188 & 22.7 \\
\hline Oromo & 488 & 58.8 \\
\hline Guragie & 97 & 11.7 \\
\hline Tigre & 37 & 4.5 \\
\hline Others & 20 & 2.4 \\
\hline \multicolumn{3}{|l|}{ Marital status } \\
\hline Single & 49 & 5.9 \\
\hline Married & 659 & 79.4 \\
\hline Divorced & 46 & 5.5 \\
\hline Widowed & 74 & 8.9 \\
\hline Separated & 2 & .2 \\
\hline \multicolumn{3}{|l|}{ Occupation } \\
\hline Farmer & 43 & 5.2 \\
\hline Housewife & 213 & 25.7 \\
\hline Merchant & 288 & 34.7 \\
\hline Daily Laborer & 167 & 20.1 \\
\hline Priv. Com. Employee & 3 & .4 \\
\hline Self-employed & 15 & 1.8 \\
\hline Others & 101 & 12.2 \\
\hline \multicolumn{3}{|l|}{ Educational status } \\
\hline Can't read and write & 43 & 5.2 \\
\hline
\end{tabular}

Table 1 Distribution of socio-demographic characteristics of respondents who participated in the survey, urban towns of Oromia, 2018, Ethiopia (Continued)

\begin{tabular}{lll}
\hline Variables & Frequency & Percent (\%) \\
\hline Read and write & 69 & 8.3 \\
Grade 1-8 & 204 & 24.6 \\
Grade 9-12 & 293 & 35.3 \\
Certificate/Diploma & 178 & 21.4 \\
Degree and above & 43 & 5.2 \\
Family size & & \\
$<3$ & 296 & 35.7 \\
$3-6$ & 455 & 54.8 \\
$>6$ & 79 & 9.5 \\
Pregnancy & & \\
Yes & 154 & 18.6 \\
No & 676 & 81.4 \\
Participation in Iddir & & 75.9 \\
Yes & 630 & 24.1 \\
No & 200 & \\
\hline
\end{tabular}

care cost for the last 12 months was less than 1000 ETB for $386(77 \%)$ of the respondents; 481 (96\%) said it's covered by themselves and getting that money was very difficult for 197 (39.2\%) of them. And 353 (42.5\%) responded that it took 10-20 min to reach the health facility. To 326 $(39.3 \%)$ of the respondents, a private clinic is the nearest followed by health center for 206 (24.8\%). 437 (52.7\%) can raise 200 Ethiopian birr (ETB) within a week in case of emergency and it's from their own cash for 242 (55.4\%) of them. A merchant is the main source of income for 323 (39\%) of the respondents (Table 3).

\section{Awareness, willingness to uptake and ability to pay for $\mathrm{CBHI}$}

From total respondents 619 (74.6\%) had heard about $\mathrm{CBHI}$; from these 473 (57\%) know the benefits package of CBHI. Among respondents $716(86.3 \%)$ were willing to uptake CBHI; out of this 688 (83.9\%) were willing to pay, and $415(58 \%)$ were able to pay 500ETB as annual premium for CBHI. The reason to uptake CBHI for 259 (36.2\%) of the participants was for security and peace of mind in times of ill-health. About 50 (46.3\%) out of 108 respondents not willing to uptake $\mathrm{CBHI}$, were as a result of not having enough money and around 30 (46.9\%) out of 64 respondents not willing to pay for $\mathrm{CBHI}$, was due to a shortage of money. The study indicated that 278 (39.3\%) wanted to pay the premium bi-annually followed by $230(32.5 \%)$ wanting to pay annually (Table 4 ), (Fig. 2). 
Table 2 Distribution of social capital and horizontal trust among respondents, Oromia, 2018, Ethiopia

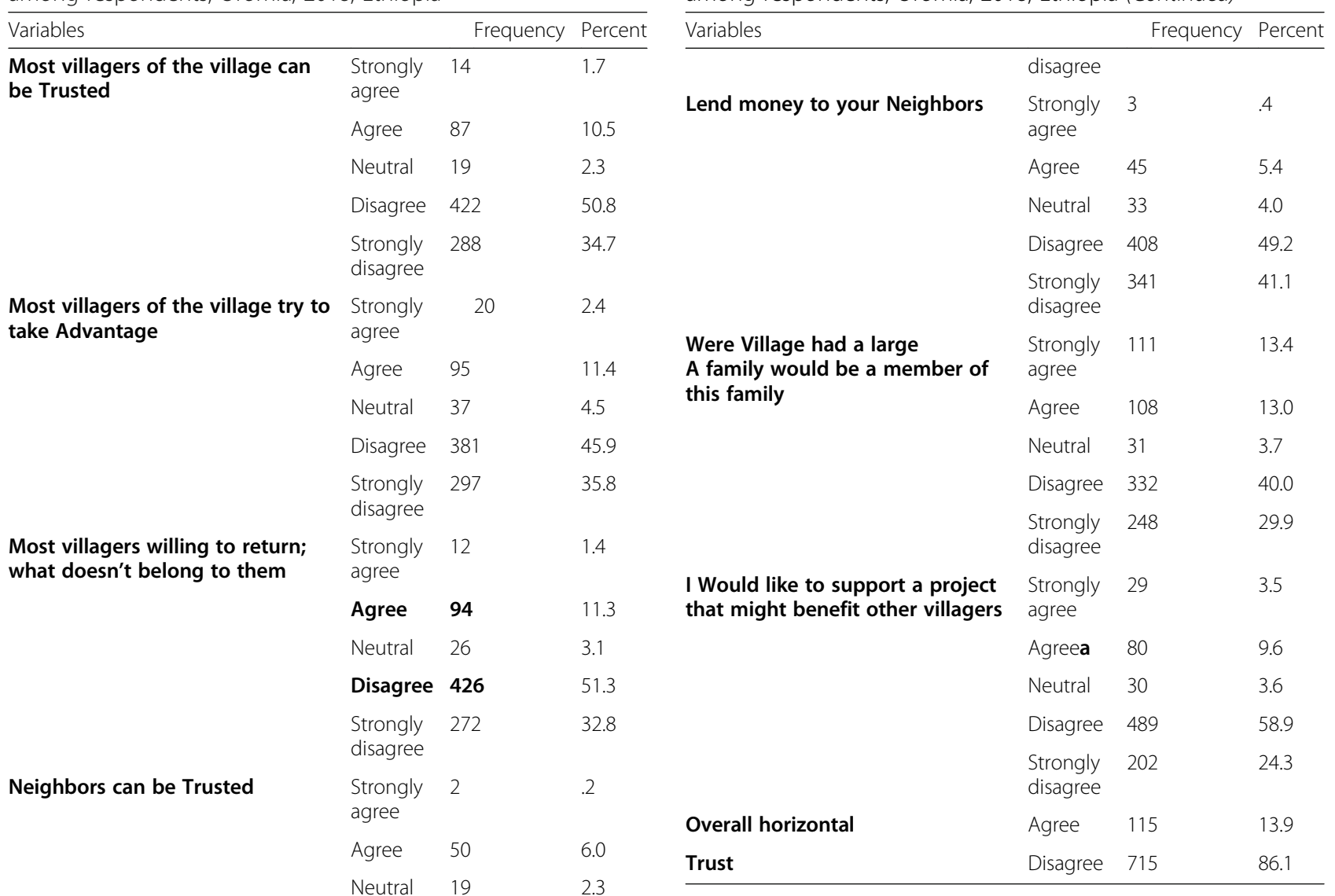

Strongly $339 \quad 40.8$

disagree

Village leaders are Trusted

Villagers concern issues not only relate to themselves

$\begin{array}{llll} & \text { Agree } & 98 & 11.8 \\ & \text { Neutral } & 25 & 3.0 \\ & \text { Disagree } & 409 & 49.3 \\ & \begin{array}{l}\text { Strongly } \\ \text { disagree }\end{array} & 270 & 32.5 \\ \text { Villagers provide help if someone } & \text { Strongly } & 7 & \\ \text { really needs it } & \text { agree } & & \\ & \text { Agree } & 58 & 7.0 \\ \text { Neutral } & 29 & 3.5 \\ & \text { Disagree } & 430 & 51.8 \\ \text { Strongly } & 306 & 36.9\end{array}$

Table 2 Distribution of social capital and horizontal trust among respondents, Oromia, 2018, Ethiopia (Continued)

Risk factors for the willingness of $\mathrm{CBHI}$ uptake

Multivariable logistic regression analyses were conducted to explore the association between dependent and independent variables. So, the study showed that the odds of willingness to utilize CBHI are associated with educational status, family size, easiness of getting money to pay for health care services; the time it took to reach the nearest health facility and frequency at which the respondents want to pay the yearly premium.

Accordingly having a certificate/diploma, learning from grade $1-8$ and able to read and write were 3.38 (AOR 3.38; 95\% CI: 1.27, 8.98), 2.90 (AOR 2.9; 95\% CI: 1.16, 7.30) and 3.84 (AOR 3.84; 95\% CI: 1.23, 12.01) times higher odds compared to can't read and write, respectively; after controlling for other effects. Respondents had a family size of 3-6 had higher odds of willingness to utilize $\mathrm{CBHI}$ compared to with the family size of less than three (AOR $=1.95,95 \% \mathrm{CI}: 1.21-3.15)$. The odds of the willingness of CBHI uptake among respondents with very difficult and difficult in getting money to pay for the health care were 82 and $83 \%$ less than those without difficulty (AOR $=0.18,95 \% \mathrm{CI}: 0.07-$ $0.49)$ and $(\mathrm{AOR}=0.17,95 \% \mathrm{CI}$ : 0.06-0.46), respectively. 
Table 3 Distribution of health and health-related factors among respondents, Oromia, 2018, Ethiopia

\begin{tabular}{|c|c|c|c|}
\hline Health status of the & Very poor & 17 & 2.0 \\
\hline \multirow[t]{4}{*}{ Family } & Poor & 31 & 3.7 \\
\hline & Medium & 251 & 30.2 \\
\hline & Good & 380 & 45.8 \\
\hline & Very good & 151 & 18.2 \\
\hline \multirow{2}{*}{$\begin{array}{l}\text { Have chronic illness } \\
\text { and/or disability }\end{array}$} & Yes & 95 & 11.4 \\
\hline & No & 735 & 88.6 \\
\hline \multirow{2}{*}{$\begin{array}{l}\text { You encountered any } \\
\text { illness in the last } \\
12 \text { months }\end{array}$} & Yes & 485 & 58.4 \\
\hline & No & 345 & 41.6 \\
\hline \multirow{2}{*}{$\begin{array}{l}\text { member of the family } \\
\text { encountered any illness } \\
\text { during the last } 12 \text { months }\end{array}$} & Yes & 516 & 62.2 \\
\hline & No & 314 & 37.8 \\
\hline \multirow[t]{6}{*}{ Latest illness episode Occur } & Before one year & 50 & 6.0 \\
\hline & $\begin{array}{l}\text { Within the last 7- } \\
12 \text { Months }\end{array}$ & 136 & 16.4 \\
\hline & $\begin{array}{l}\text { Within the last 4- } \\
6 \text { Months }\end{array}$ & 117 & 14.1 \\
\hline & $\begin{array}{l}\text { Within the last 2- } \\
3 \text { Months }\end{array}$ & 71 & 8.6 \\
\hline & $\begin{array}{l}\text { Within the last } 1 \\
\text { Month }\end{array}$ & 142 & 17.1 \\
\hline & Total & 516 & 62.2 \\
\hline \multirow[t]{10}{*}{ Get treatment Facility } & Yes & 501 & 60.4 \\
\hline & No & 15 & 2.0 \\
\hline & Total & 516 & 62.4 \\
\hline & home treatment & 11 & 1.3 \\
\hline & $\begin{array}{l}\text { Local drug } \\
\text { vendor }\end{array}$ & 6 & .7 \\
\hline & $\begin{array}{l}\text { Private Health } \\
\text { Facility }\end{array}$ & 216 & 26.0 \\
\hline & $\begin{array}{l}\text { Public health } \\
\text { center }\end{array}$ & 110 & 13.3 \\
\hline & Public hospital & 150 & 18.1 \\
\hline & Traditional healer & 8 & .9 \\
\hline & Total & 501 & 60.4 \\
\hline \multirow[t]{6}{*}{ Reason to go to HF } & $\begin{array}{l}\text { The HF was } \\
\text { physically } \\
\text { accessible }\end{array}$ & 111 & 13.4 \\
\hline & $\begin{array}{l}\text { The HF was not } \\
\text { expensive }\end{array}$ & 158 & 19.0 \\
\hline & $\begin{array}{l}\text { The health facility } \\
\text { not too crowded }\end{array}$ & 21 & 2.5 \\
\hline & $\begin{array}{l}\text { The health } \\
\text { service was } \\
\text { courteous }\end{array}$ & 31 & 3.7 \\
\hline & $\begin{array}{l}\text { The health } \\
\text { service was } \\
\text { efficacious/ } \\
\text { Effective }\end{array}$ & 180 & 21.7 \\
\hline & System & 329 & 39.6 \\
\hline
\end{tabular}

Table 3 Distribution of health and health-related factors among respondents, Oromia, 2018, Ethiopia (Continued)

\begin{tabular}{llll}
\hline Health status of the & Very poor & 17 & 2.0 \\
\hline $\begin{array}{l}\text { Reason for not } \\
\text { getting Rx }\end{array}$ & $\begin{array}{l}\text { Considering the } \\
\text { illness is self- } \\
\text { Limiting }\end{array}$ & 10 & 1.2 \\
& $\begin{array}{l}\text { No enough } \\
\text { money }\end{array}$ & 7 & .8 \\
& Total & 17 & 2.0 \\
& System & 813 & 98.0 \\
& $<2$ & 477 & 92.4 \\
No of illness & $2-4$ & 36 & 7.0 \\
& $>4$ & 3 & .6 \\
& Total & 516 & 100.0 \\
& $<1000$ & 386 & 77.0 \\
Total HC cost & $1000-3000$ & 87 & 17.4 \\
& $>3000$ & 28 & 5.6 \\
& Total & 501 & 100.0 \\
Time to reach HF & $<10$ min & 262 & 31.6 \\
in Min & $10-20$ min & 353 & 42.5 \\
& $>20$ min & 215 & 25.9
\end{tabular}

\section{Variables}

Frequency Valid

HC cost covered by

$\begin{array}{lll}\text { Self } & 481 & 96.0 \\ \text { Government/free } & 3 & .6 \\ \text { Community } & 5 & 1.0 \\ \text { Others } & 12 & 2.4 \\ \text { Strongly agree } & 98 & 19.5 \\ \text { Agree } & 79 & 15.7 \\ \text { Neutral } & 77 & 15.3 \\ \text { Disagree } & 157 & 31.2 \\ \text { Strongly disagree } & 90 & 18.3 \\ \text { Total } & 501 & 100.0 \\ \text { Very difficult } & 197 & 39.2 \\ \text { Difficult } & 161 & 32.1 \\ \text { Not difficult } & 144 & 28.7 \\ \text { Total } & 502 & 100.0 \\ \text { Self } & 481 & 96.0 \\ \text { Government/free } & 3 & .6 \\ \text { Community } & 5 & 1.0 \\ \text { Others } & 12 & 2.4 \\ \text { Total } & 501 & 100.0 \\ \text { Yes } & 153 & 18.4 \\ \text { No } & 677 & 81.6 \\ \text { Health center } & 206 & 24.8 \\ \text { Clinic (Private) } & 326 & 39.3 \\ \text { private hospital } & 90 & 10.8\end{array}$


Table 3 Distribution of health and health-related factors among respondents, Oromia, 2018, Ethiopia (Continued)

\begin{tabular}{|c|c|c|c|}
\hline Health status of the & Very poor & 17 & 2.0 \\
\hline & Hospital (Gov.) & 176 & 21.2 \\
\hline & $\begin{array}{l}\text { Non-Gov'tal } \\
\text { health facilities }\end{array}$ & 32 & 3.9 \\
\hline \multirow{2}{*}{$\begin{array}{l}\text { Raise } 200 \text { Birr within } \\
\text { a week In case of emergency }\end{array}$} & Yes & 437 & 52.7 \\
\hline & No & 393 & 47.3 \\
\hline HH obtain the 200 & $\begin{array}{l}\text { sale of the } \\
\text { animal. }\end{array}$ & 14 & 3.2 \\
\hline \multirow[t]{15}{*}{ ETB from } & $\begin{array}{l}\text { and animal } \\
\text { product }\end{array}$ & & \\
\hline & sale of crops & 27 & 6.2 \\
\hline & $\begin{array}{l}\text { sale of forest } \\
\text { products }\end{array}$ & 6 & 1.4 \\
\hline & own cash & 242 & 55.4 \\
\hline & bank saving & 95 & 21.7 \\
\hline & Equb & 4 & .9 \\
\hline & Iddir & 5 & 1.1 \\
\hline & $\begin{array}{l}\text { loan from a bank } \\
\text { or other } \\
\text { institutions }\end{array}$ & 6 & 1.4 \\
\hline & $\begin{array}{l}\text { loan from } \\
\text { relatives }\end{array}$ & 6 & 1.4 \\
\hline & $\begin{array}{l}\text { gifts from } \\
\text { relatives }\end{array}$ & 2 & .5 \\
\hline & $\begin{array}{l}\text { loan from non- } \\
\text { relatives }\end{array}$ & 7 & 1.6 \\
\hline & $\begin{array}{l}\text { sale of household } \\
\text { assets }\end{array}$ & 11 & 2.5 \\
\hline & $\begin{array}{l}\text { sale of personal } \\
\text { item (Jewelries, } \\
\text { etc.) }\end{array}$ & 7 & 1.6 \\
\hline & Other (specified) & 5 & 1.1 \\
\hline & Total & 437 & 100.0 \\
\hline \multirow{9}{*}{$\begin{array}{l}\text { The main source } \\
\text { of Income }\end{array}$} & Merchant & 323 & 39 \\
\hline & Pension & 43 & 5.2 \\
\hline & Selling Injera & 125 & 15 \\
\hline & Grocery & 62 & 7.5 \\
\hline & Renting house & 47 & 5.7 \\
\hline & Private work & 113 & 13.6 \\
\hline & Sewing clothes & 59 & 7 \\
\hline & Daily laborer & 33 & 4 \\
\hline & Others & 25 & 3 \\
\hline
\end{tabular}

Time to reach the nearest health facility in $<10 \mathrm{~min}$ and $10-20 \mathrm{~min}$ were 63 and $75 \%$ less likely willing to join CBHI when compared to the time it took $>20$ mins. Ability to raise 200ETB during emergency had an association with willingness to uptake $\mathrm{CBHI}(\mathrm{COR}=2.02,95 \%$ CI: 1.35-3.03); but it doesn't have an association when adjusted (Table 5).

\section{Discussion}

Community-based health insurance (CBHI) is one of the ways to provide health insurance for the informal sector and the rural populace. CBHI, in spite of its problems relating to the extent of resource pooling, has been shown to facilitate and improve access to healthcare services especially among children, pregnant women and the elderly.

The overall aim of this study was to assess the willingness of CBHI uptake and associated factors among the informal sector workers in urban towns. The proportion of willingness of CBHI uptake was $86.3 \%$. Educational status, family size, easiness of getting money to pay for health care services; the time it took to reach the nearest health facility and frequency at which the respondents want to pay the yearly premium were the associated factors for the willingness of CBHI uptake.

Age of the respondents, wealth, knowing the benefits package of CBHI and ability to pay 500 ETB (USD \$17.9) as annual premium were variables having a statistically significant association with the willingness of CBHI uptake in crude; but have no association when adjusted. Age with $45-54$ categories was $4.51(\mathrm{COR}=4.51$ : $95 \% \mathrm{CI}, 1.5-13.58)$ times more likely willing to uptake CBHI than 15-24 age category. Those able to raise 200 ETB (USD \$7.14) during the emergency were 2.02 times more likely to enroll in CBHI than their counterparts $(\mathrm{COR}=2.02$ : $95 \% \mathrm{CI}$, 1.35 3.03). Knowing the benefits package of CBHI make the respondents wish to join CBHI $(\mathrm{COR}=2.49$ : $95 \% \mathrm{CI}, 1.61-$ 3.83). And an ability to pay 500 ETB (USD \$17.9) as annual premium made them will to uptake $\mathrm{CBHI}(\mathrm{COR}=$ 21.62: 95\%CI, 7.62-61.32).

The willingness of CBHI uptake of this survey is similar to a previously conducted survey in Cameroon $86.2 \%$ [12]. This proportion finding is higher than research conducted in Ecuador 69.3\% [13]. This high discrepancy may be related to methodological issues and differences in the study areas. But, the current finding is less than that found in 2004 in Ethiopia, in which the probability of willingness to join the scheme was 94.7\% [14]. The reason may be attributed to differences in the study areas and time of the study.

Having an educational level of a certificate/diploma were 3.38 times more likely to uptake $\mathrm{CBHI},(\mathrm{AOR}=$ 3.38: $95 \% \mathrm{CI}, 1.27-8.98$ ). This finding is supported by another study, in which persons having higher education level were willing to uptake CBHI [15]. It is also supported by a study conducted in Osun State, Nigeria where people with low level of education were less willing to join CBHI [16].

In this finding, respondents with 3-6 family sizes were about two times more likely willing to join CBHI than with less than three family sizes. This finding was also supported by other findings, in which respondents 
Table 4 Distribution of awareness on CBHI, willingness to join CBHI and ability to pay for CBHI in Oromia Region, 2018, Ethiopia

\begin{tabular}{|c|c|c|c|}
\hline \multirow{3}{*}{$\begin{array}{l}\text { Variables } \\
\text { Ever heard about CBHI }\end{array}$} & & Frequency & Percentage \\
\hline & Yes & 619 & 74.6 \\
\hline & No & 211 & 25.4 \\
\hline \multirow[t]{2}{*}{ Know the benefits package of $\mathrm{CBHI}$} & Yes & 473 & 57 \\
\hline & No & 237 & 28.6 \\
\hline \multirow[t]{5}{*}{ Benefits package of $\mathrm{CBHI}$} & Drugs & 320 & 38.6 \\
\hline & Surgery except for cosmetic Surgery & 67 & 8.1 \\
\hline & Inpatient stay & 89 & 10.7 \\
\hline & Laboratory Tests & 43 & 5.2 \\
\hline & Others & 8 & 1.0 \\
\hline \multirow[t]{7}{*}{ Heard CBHI from } & Radio & 219 & 26.4 \\
\hline & HEW & 29 & 3.5 \\
\hline & TV & 289 & 34.8 \\
\hline & Neighbor & 37 & 4.5 \\
\hline & Leader of HAD & 42 & 5.1 \\
\hline & Others & 2 & .2 \\
\hline & Missing & 212 & 25.5 \\
\hline Variables & & Frequency & Percent \\
\hline Willing to & Yes & 716 & 86.3 \\
\hline uptake $\mathrm{CBHI}$ & No & 114 & 13.7 \\
\hline \multirow[t]{6}{*}{ Reason to uptake CBHI } & It provides free access to medical care & 243 & 33.9 \\
\hline & To help others & 68 & 9.5 \\
\hline & For security and peace of mind in times of ill- Health & 259 & 36.2 \\
\hline & Facing health problem & 15 & 2.1 \\
\hline & $\begin{array}{l}\text { Frequently unable to cover medical care cost at the time of ill- } \\
\text { health }\end{array}$ & 117 & 16.3 \\
\hline & Other & 14 & 2.0 \\
\hline \multirow[t]{3}{*}{ Reason for not join the scheme } & not have enough money to pay & 50 & 46.3 \\
\hline & Do not need health insurance & 34 & 31.5 \\
\hline & Other & 24 & 22.2 \\
\hline \multirow[t]{2}{*}{ Willing to pay for CBHI } & Yes & 688 & 96.2 \\
\hline & No & 28 & 3.8 \\
\hline \multirow[t]{2}{*}{ Can pay 500ETB/year } & Yes & 415 & 58.0 \\
\hline & No & 301 & 42.0 \\
\hline \multirow[t]{2}{*}{ Pay the initial bid as annual premium/HH for $\mathrm{CBHI}$} & Yes & 404 & 64.2 \\
\hline & No & 225 & 35.8 \\
\hline \multirow[t]{2}{*}{ Pay if the premium is double } & Yes & 165 & 27.9 \\
\hline & No & 426 & 72.1 \\
\hline \multirow[t]{2}{*}{ Pay if the premium is halved } & Yes & 362 & 74.2 \\
\hline & No & 126 & 25.8 \\
\hline \multirow[t]{3}{*}{ Max. pay/year as a premium } & $<500$ & 397 & 47.3 \\
\hline & $500-1000$ & 114 & 13.6 \\
\hline & $>1000$ & 66 & 7.9 \\
\hline \multirow{2}{*}{$\begin{array}{l}\text { The reason the HH not willing to pay for the } \\
\text { scheme }\end{array}$} & Doubt the management of the fund & 10 & 15.6 \\
\hline & Because of lack of money & 30 & 46.9 \\
\hline
\end{tabular}


Table 4 Distribution of awareness on CBHI, willingness to join CBHI and ability to pay for $\mathrm{CBHI}$ in Oromia Region, 2018, Ethiopia (Continued)

\begin{tabular}{|c|c|c|c|}
\hline Variables & & Frequency & Percentage \\
\hline & Out-of-pocket payment is better than CBHI scheme & 17 & 26.6 \\
\hline & Others & 7 & 10.9 \\
\hline \multirow[t]{5}{*}{ Frequency want to pay the yearly premium } & Annual flat rate & 230 & 32.5 \\
\hline & Bi-annual flat-rate & 278 & 39.3 \\
\hline & Quarterly a year flat-rate & 144 & 20.3 \\
\hline & Monthly & 46 & 6.5 \\
\hline & Others & 10 & 1.4 \\
\hline
\end{tabular}

having a large family had a positive association with willingness to uptake CBHI $[17,18]$.

Different researches showed that, the wealth or socioeconomic standing of households and individuals is associated with the uptake of CBHI [11, 17]. A similar finding was also observed in India that; wealth was associated with uptake of CBHI [18]. Our study supported the above finding in which a respondent with difficulty in paying for the health care was $82 \%$ less likely to uptake CBHI compared to those with no difficulty. From this premise, it is conceivable to find that the poor are unwilling to uptake the scheme.

In terms of time taken to reach the nearest health facility within $20 \mathrm{~min}$ was also found to affect enrolment to $\mathrm{CBHI}$. This finding was supported by other studies conducted in low and middle-income countries [16].

\section{Limitation of the study}

The Contingent Valuation Method has the limitation of testing consumers' demand; that means CVM cannot approve whether the consumer actually pays the number of premiums that they said for the study and the study only shows the temporal link between dependent and independent variables.

Double-bounded dichotomous choice contingent valuation method may result in inflated value because respondents may say "yes" for the amount of money they will be asked to pay and it has starting point bias.

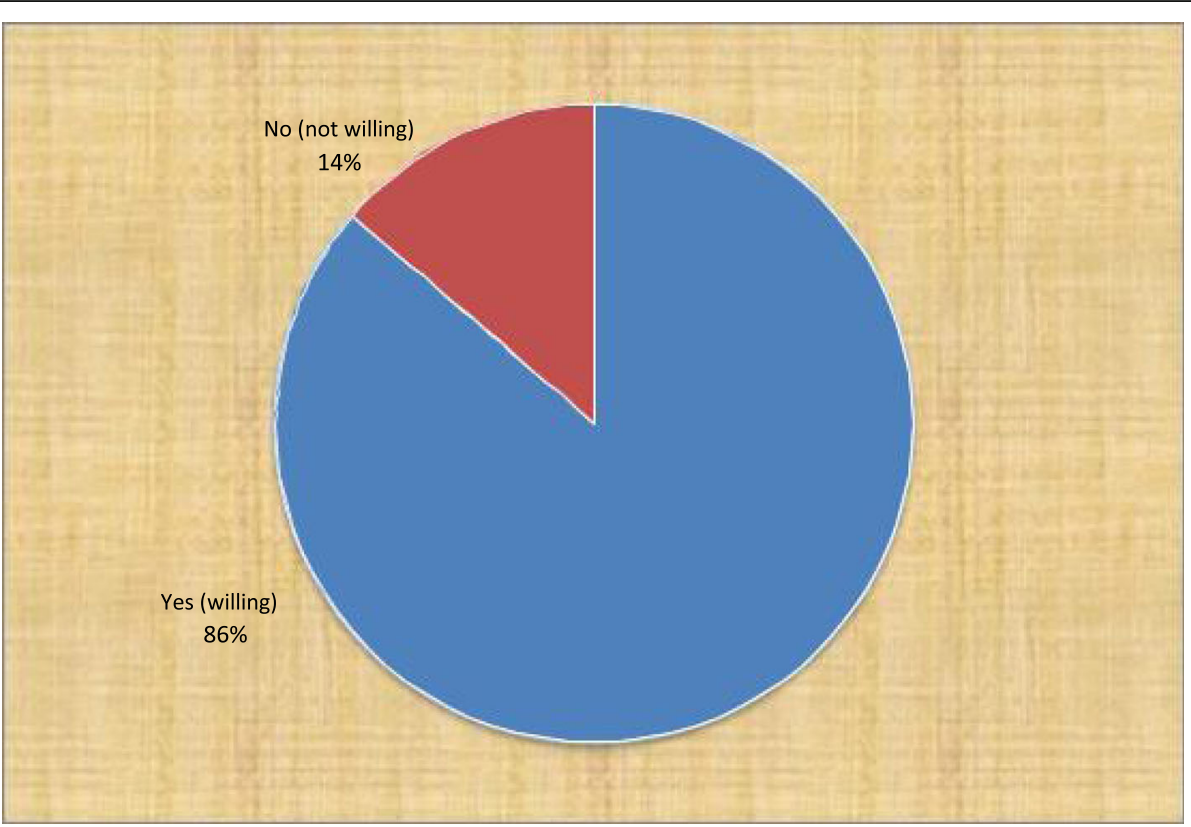

Fig. 2 Willingness of CBHI uptake if established in urban towns of Oromia, 2018, Adama, Ethiopia 
Table 5 Risk factors for the willingness of CBHI uptake in survey data in urban towns in Oromia region, 2018, Ethiopia

\begin{tabular}{|c|c|c|c|c|}
\hline \multirow[t]{2}{*}{ Variables } & \multicolumn{2}{|c|}{ Willingness to join $\mathrm{CBHI}$} & \multirow[t]{2}{*}{ Crude OR (95\% Cl) } & \multirow{2}{*}{$\begin{array}{l}\text { Adjusted OR } \\
(95 \% \mathrm{Cl})\end{array}$} \\
\hline & Yes (\%) & No (\%) & & \\
\hline \multicolumn{5}{|l|}{ Age of the respondents } \\
\hline $15-24$ & 19 & 6 & 1 & 1 \\
\hline $25-34$ & 180 & 41 & $1.39(0.52,3.69)$ & $0.40(0.70,2.28)$ \\
\hline $35-44$ & 274 & 41 & $2.11(0.70,5.59)$ & $0.52(0.09,2.99)$ \\
\hline $45-54$ & 157 & 11 & $4.51(1.50,13.58)^{* *}$ & $1.04(0.17,6.49)$ \\
\hline$>54$ & 86 & 15 & $1.81(0.62,5.27)$ & $0.38(0.06,2.39)$ \\
\hline \multicolumn{5}{|l|}{ Educational status } \\
\hline Can't read and Write & 33 & 10 & 1 & 1 \\
\hline Can read and write & 63 & 6 & $3.18(1.06,9.52)$ & $3.84(1.23,12.01)^{*}$ \\
\hline Grade 1-8 & 184 & 20 & $2.79(1.20,6.49)$ & $2.90(1.16,7.30)^{*}$ \\
\hline Grade 9-12 & 236 & 54 & $1.26(0.58,2.70)$ & $1.38(0.58,3.33)$ \\
\hline Certificate/diploma & 161 & 17 & $2.87(1.21,6.82)$ & $3.38(1.27,8.98)^{* *}$ \\
\hline 1st degree and above & 39 & 4 & $2.96(0.85,10.30)$ & $2.79(0.17,10.87)$ \\
\hline \multicolumn{5}{|l|}{ Family size } \\
\hline$<3$ & 238 & 58 & 1 & 1 \\
\hline $3-6$ & 410 & 45 & $2,22(1.46,3.38)$ & $1.95(1.21,3.15)^{* *}$ \\
\hline$>6$ & 68 & 11 & $1.51(0.75,3.03)$ & $1.21(0.55,2.68)$ \\
\hline \multicolumn{5}{|c|}{ Getting money to pay for health care } \\
\hline Very difficult & 164 & 33 & $0.23(0.10,0.55)$ & $0.18(0.07,0.49)^{* * *}$ \\
\hline Difficult & 132 & 29 & $0.25(0.12,0.59)$ & $0.17(0.06,0.46)^{* * *}$ \\
\hline Not difficult & 137 & 7 & 1 & 1 \\
\hline \multicolumn{5}{|c|}{ Time to reach nearest health facility } \\
\hline$<10$ mins & 217 & 45 & $0.69(0.40,1.18)$ & $0.37(0.17,0.80)^{* *}$ \\
\hline $10-20 \mathrm{~min}$ & 305 & 48 & $0.52(0.30,0.91)$ & $0.25(0.11,0.58)^{* * *}$ \\
\hline$>20$ mins & 194 & 21 & 1 & 1 \\
\hline \multicolumn{5}{|c|}{ Able to raise 200ETB during emergency } \\
\hline Yes & 394 & 43 & $2.02(1.35,3.03)^{* *}$ & $1.06(0.58,1.97)$ \\
\hline No & 322 & 71 & 1 & 1 \\
\hline \multicolumn{5}{|c|}{ Know the benefits package of $\mathrm{CBHI}$} \\
\hline Yes & 426 & 47 & $2.49(1.61,3.83)^{* *}$ & $2.78(0.61,10.77)$ \\
\hline No & 186 & 51 & 1 & 1 \\
\hline \multicolumn{5}{|c|}{ can pay $500 E T B$ as annual premium } \\
\hline Yes & 400 & 4 & $21.62(7.62,61.32)^{*}$ & $1.08(0.47,17.56)$ \\
\hline No & 185 & 40 & 1 & 1 \\
\hline
\end{tabular}

NB: ${ }^{*}=$ significant, ${ }^{*} p<0.05,{ }^{* *} p<0.01$ and ${ }^{* * *} p<0.001$

As the study employed an interviewer administered questionnaire that might result social desirability and recall bias.

\section{Conclusions}

Despite the above limitations, in urban towns of Oromia regional state, if $\mathrm{CBHI}$ established about $86.3 \%$ of the households would enroll in the scheme. Having education, with a family size between three \& six, and less than 20 min it took to reach the nearest health facility were positively associated with the odds of willingness of CBHI uptake, but having difficulty in paying for health care was negatively associated with the odds of willingness of CBHIU.

\section{Abbreviations}

CBHF: Community-Based Health Financing; CBHI: Community-Based Health Insurance; CBHIU: Community-Based Health Insurance Uptake;

$\mathrm{CHI}$ : Community health insurance; EHSFR: Ethiopia health sector financing 
reform.; ETB: Ethiopian Birr; FMOH: Federal ministry of health; HH: Household; HSFRP: Health sector financing reform program; LMIC: Low and middleincome country; MINS: Minutes; OOP: Out-of-pocket payment; ORHB: Oromia regional health bureau; PCA: Principal component analysis; SPSS: Statistical software for social science; USD: United States dollar; WHO: World Health Organization; WTJ: Willingness to join; WTP: Willingness to pay; WTU: Willingness to Uptake

\section{Acknowledgments}

We acknowledge Oromia Regional Health Bureau, Italian corporation and Adama Hospital Medical College.

\section{Authors' contributions}

Design and conception of the study: AZ, ML, AD, HL, MA, EM, TD, SG, ID, and DA; Performed the study: AD, MA, EM, DT, SG, HL, AZ and ML; Data analysis and interpretation: $A D, M A$ and $H L$; Writing of the manuscript: $A D, M A$; All authors read and approved the final manuscript.

\section{Funding}

No fund was obtained for this study.

\section{Availability of data and materials}

Data and materials are available and can be shared by the corresponding author.

\section{Ethics approval and consent to participate}

The study was reviewed and approved by the Ethical Clearance Committee of Oromia regional Health bureau, Addis Ababa, Ethiopia. Permission letter was obtained from selected study urban and communicated with Kebele leaders. The purpose and the importance of the study were explained and verbal consent was obtained from the parents/guardians of the minors and from each participant (above the age of 16). The verbal consent was prefered because of its adequacy for questionnaire surveys of a non-sensitive nature. Moreover, confidentiality of the information was guaranteed by using unspecified questionnaires and by keeping the data in a secured place.

\section{Consent for publication}

'Not Applicable'.

\section{Competing interests}

There is no competing interest among the authors.

\section{Author details}

'Department of Public Health, Adama Hospital Medical College, Adama, Ethiopia. ${ }^{2}$ Oromia Regional Health Bureau, Addis Ababa, Ethiopia.

Received: 20 June 2019 Accepted: 27 July 2020

Published online: 16 September 2020

\section{References}

1. Ranson MK. Reduction of catastrophic health care expenditures by a community-based health insurance scheme in Gujarat, India: current experiences and challenges. Bull World Health Organ. 2002;80:613-21.

2. WHO (World Health Organization). The world health report: health systems financing: the path to universal coverage. Geneva; 2010.

3. Wang $\mathrm{H}$, Pielemeier N. CBHI: an evolutionary approach to achieving universal coverage in low-income countries. J Life Sci. 2012;6:320-9.

4. Approach to Achieving Universal Coverage in Low-Income Countries." J Life Sci. 6: 320-9..

5. USAID. Ethiopia health sector financing reform midterm project evaluation 2011.

6. Adane K, Masho G, Mezgebu Y. Willingness to pay for community-based health insurance among households in the rural community of Fogera District, north West Ethiopia. Int J Econ Finance Manag Sci. 2014;2(4):263-9.

7. Federal Ministry of Health. Ethiopia Health Sector Development Program IV Version 1, Annual Performance Report 2012/13.

8. USAID. Financial and administrative system manual for community-based health insurance schemes of Ethiopia. A prototype for regions 2010.

9. $\mathrm{FMOH}$ (Federal Ministry of Health). Ethiopia's Fifth National Health Accounts report. Addis Ababa: Federal Ministry of Health report; 2014.
10. Anagaw D. Robert S. Zelalem Y. Getnet A. Arjun S. Bedi. Enrolment in Ethiopia's Community Based Health Insurance scheme 2013; working paper.

11. Yamane T. Statistics: an introductory analysis. New York: Harper \& Row; 1973.

12. Hermann P, Pierre D, Ephias M, Pierre-Aleixandre M, Eric M. The determinants of the willingness-to-pay for community-based prepayment scheme in rural Cameroon. Int J Health Care Finance Econ. 2011;11:209-20.

13. Eckhardt M, Forsberg BC, Wolf D, Crespo-Burgos A. Feasibility of community-based health insurance in rural tropical Ecuador. Rev Panam Salud Publica. 2011;29(3):177-84.

14. Asfaw A, Braun J. Can community health insurance schemes shield the poor against the downside health effects of economic reforms? The case of rural Ethiopia. Health Policy. 2004;70:97-108.

15. Shimeles $\mathrm{O}$, Challi J, Yohannes H, Belaineh G. Indigenous community insurance (Iddirs) as an alternative health care financing in Jimma City, Southwest Ethiopia. Ethiop J Health Sci. 2009;19:19-37.

16. Usman AB. Willingness to pay for community based health care financing scheme: a comparative study among rural and urban households in Osun state, Nigeria. J Dental Med Sci. 2013;5(6):27-40.

17. Zelalem Y, Robert S, Marleen D, Getnet A, Arjun S. Bedi. Impact of Ethiopia's Community Based Health Insurance on household economic welfare, vol. 590; 2014; ISS working paper No.

18. Bennett S, Creese A, Monasch R. Health insurance schemes for people outside formal sector employment. Geneva: World Health Organization; 1998.

\section{Publisher's Note}

Springer Nature remains neutral with regard to jurisdictional claims in published maps and institutional affiliations.

\section{Ready to submit your research? Choose BMC and benefit from:}

- fast, convenient online submission

- thorough peer review by experienced researchers in your field

- rapid publication on acceptance

- support for research data, including large and complex data types

- gold Open Access which fosters wider collaboration and increased citations

- maximum visibility for your research: over $100 \mathrm{M}$ website views per year

At BMC, research is always in progress.

Learn more biomedcentral.com/submissions 